\title{
Ameliorative Potential of Rosuvastatin on Doxorubicin-induced Cardiotoxicity by Modulating Oxidative Damage in Rats
}

\author{
Sıçanlarda Oksidatif Hasar Modülasyonuyla Doksorubisinin İndüklediği \\ Kardiyotoksisite Üzerine Rosuvastatinin İyileştirici Potansiyeli
}

\author{
(D) Saumya DAS 6 , (D) Krishnapillai MATHUSOOTHANAN7 \\ 1Sree Vidyanikethan College of Pharmacy, Department of Pharmacology, Andhra Pradesh, India \\ 2Sree Vidyanikethan College of Pharmacy, Department of Pharmaceutics, Andhra Pradesh, India \\ 3The Neotia University School of Pharmacy, Department of Pharmaceutics, West Bengal, India \\ ${ }^{4}$ Amity University Amity Institute of Pharmacy, Department of Pharmacology, Madhya Pradesh, India \\ 5 Orlean College of Pharmacy, Department of Pharmacology, Uttar Pradesh, India \\ 6NIET College of Pharmacy, Department of Pharmacology, Uttar Pradesh, India \\ ${ }^{7}$ Grace College of Pharmacy, Department of Pharmaceutics, Kerala, India
}

(D) Jayaraman RAJANGAM ${ }^{1 *}$, (D) Navaneetha KRISHNAN S1, (D) Narahari N PALEI 2,3 , (D) Shvetank BHATT ${ }^{4}$, (D) Manas Kumar DAS ${ }^{5}$

\begin{abstract}
Objectives: The study aimed to explore the in vivo protective potential of rosuvastatin (ROSS), an oral antihyperlipidemic drug against doxorubicin (DOXO) induced cardio toxicity in rats.

Materials and Methods: Cardiac toxicity was induced by DOXO injection $\left(10 \mathrm{mg} / \mathrm{kg}\right.$, i.p.), once on the $20^{\text {th }}$ day of the experiment. Except for the control rats, all were received DOXO and the study was continued for up to 21 days. The influence of ROSS on acute treatment was analyzed by quantification of cardiac marker enzymes such as creatine kinase-MB (CK-MB), lactate dehydrogenase (LDH) and liver marker enzymes like aspartate aminotransferase (AST), alanine aminotransferase (ALT) along with the measurement of in vivo antioxidants like superoxide dismutase and catalase. To observe histological changes of myocardial tissue hematoxylin and eosin staining were used.

Results: Acute administration of DOXO resulted in a marked rise of cardiac marker enzymes that confirms the myocardial damage compared to control animals whereas administration of ROSS (10 mg/kg, p.o.) resulted in the significant reduction of CK-MB, LDH levels ( $p<0.05$ ) and AST, ALT levels to a remarkable extent. Moreover, ROSS administration significantly increased the activities of various in vivo antioxidant levels.

Conclusion: From the results, the acute administration of ROSS showed significant cardioprotective property, which was evidenced by a significant reduction of cardiac and liver marker enzymes along with significant improvement of in vivo antioxidant activities. Furthermore the results were supported with histopathological observations. Hence, it can be concluded that cardioprotective potential of ROSS may be through attenuation of oxidative stress by modulating oxidative damage in rats.
\end{abstract}

Key words: Cardioprotection, rosuvastatin, doxorubicin, cardiotoxicity, cardiac markers, antioxidants

Öz

Amaç: Çalışma, sıçanlarda doksorubisin (DOXO) indüklediği kardiyotoksisiteye karșı oral antihiperlipidemik bir ilaç olan rosuvastatinin (ROSS) in vivo koruyucu potansiyelini araştırmayı amaçlamıştır. Kardiyak toksisite, deneyin 20. gününde bir kez DOXO enjeksiyonu (10 mg/kg, i.p.) ile indüklenmiştir. Kontrol sıçanları hariç tümüne DOXO verildi ve çalışmaya 21 güne kadar devam edilmiştir. Akut uygulamada ROSS'nin etkisi, süperoksit dismutaz ve katalaz gibi in vivo antioksidanların ölçümü ile birlikte kreatin kinaz-MB (CK-MB), laktat dehidrojenaz (LDH) gibi kardiyak

*Correspondence: jayaraam81@gmail.com, Phone: +0877-2236711, ORCID-ID: orcid.org/0000-0002-6367-0365

Received: 17.09.2020, Accepted: 09.04.2021

๑Turk J Pharm Sci, Published by Galenos Publishing House. 
gösterge enzimlerin ve aspartat aminotransferaz (AST), alanin aminotransferaz (ALT) gibi karaciğer gösterge enzimlerinin kantitatif tayini ile analiz edilmiştir. Miyokardiyal dokudaki histolojik değişiklikleri gözlemlemek için hematoksilen ve eozin boyaması kullanılmıştır. DOXO'nun akut uygulaması, kontrol hayvanlarına kıyasla miyokardiyal hasarı doğrulayan kardiyak gösterge enzimlerinde belirgin bir artışa neden olurken, ROSS (10 $\mathrm{mg} / \mathrm{kg}$, p.o.) uygulaması CK-MB, LDH düzeylerinde $(p<0,05)$ ve AST, ALT düzeylerinde dikkate değer ölçüde önemli bir azalmaya neden olmuştur. Dahası, ROSS uygulaması, çeşitli in vivo antioksidan düzeylerinin aktivitelerini önemli ölçüde artırmıştır. Sonuçlardan, ROSS'nin akut uygulaması, kardiyak ve karaciğer gösterge enzimlerinde önemli bir azalmanın yanı sıra in vivo antioksidan aktivitelerde önemli bir iyileșme ile kanıtlanan önemli kardiyoprotektif özellik göstermiştir. Ayrıca sonuçlar histopatolojik gözlemlerle desteklenmiştir. Bu nedenle, ROSS'un kardiyoprotektif potansiyelinin, sıçanlarda oksidatif hasarı modüle ederek oksidatif stresin azaltılması yoluyla olabileceği sonucuna varılabilir.

Anahtar kelimeler: Kardiyoproteksiyon, rosuvastatin, doksorubisin, kardiyotoksisite, kardiyak göstergeler, antioksidanlar

\section{INTRODUCTION}

Incidence rates of cardiovascular disorders (CVDs) are increasing day by day around the globe, particularly developing countries like India, most mortality rates are due to CVDs despite several advances in medical treatments. Among all CVDs, ischemic heart disease (IHD) like angina pectoris, myocardial infarction (MI) is the most alarming clinical conditions and is the main principle cause of mortality even in developed countries also.

According to the current status of estimation by 2030, around 23.6 million people will die from only CVDs. Moreover, MI is considered as one of the common forms of IHD leads to irreversible necrosis of cardiac myocytes or myocardial tissue damage due to the failure of vasoregulatory or auto regulatory mechanisms. ${ }^{2}$

In addition to this, despite advances in the management of CVDs, MI remains the leading cause of mortality around the globe with high incidence rates around the age of 35 years was noticed in male patients who may be due to chronic stress, lack physical activity and lifestyle modifications, etc. ${ }^{3,4}$ Hence, there is a high demand for research, and innovations were in progress in the field of cardioprotection by employing various animal models. In this study, the doxorubicin (DOXO)-induced cardiotoxicity model was used to screen the cardioprotective potential in Wistar Albino rats.

DOXO is a potent broad-spectrum antibiotic used for treating various cancers. However, the clinical usage has been limited due to serious side effects such as myocardial injury, mainly due to mitochondrial dysfunction, apoptosis and the excess generation of free radical leads to cardio toxicity. ${ }^{5-7}$ Free radical-mediated myocardial damage is an important etiological mechanism that is associated with an increased level of reactive oxygen species and inadequate antioxidant defense system. ${ }^{8,9}$ Hence, DOXO induced $\mathrm{Ml}$ is the most widely used model to evaluate the cardioprotective effect of various drugs, and the administration of DOXO in high doses produces myocardial lesions similar to $\mathrm{Ml}$ in humans.

However, the test drug of this study rosuvastatin (ROSS) is a well-known inhibitor of the rate-limiting enzyme i.e 3-hydroxy-3-methylglutaryl-CoA (HMG-CoA reductase) for in vivo cholesterol biosynthesis. As per the data, apart from antihyperlipidemic effects, statins possess diverse pharmacological effects, including lowering the CVDs and exerts neuroprotective and antioxidant actions. ${ }^{10-13}$ However, the potential of statins on cardioprotection remains to be explored in different animal models. Therefore, we decided to put some effort to screen the cardioprotective effect of ROSS on DOXO induced cardiotoxicity in Wistar Albino rats.

\section{MATERIALS AND METHODS}

\section{Animal care and handling}

Wistar albino rats with a weight range of 140-180 g were used and housed at $25^{\circ} \pm 5^{\circ} \mathrm{C}$ until the acclimatization period of about one week at Sree Vidyanikethan College of Pharmacy, A. Rangampet, Tirupati. All the animals were maintained under standard experimental conditions according to the guidelines of the Committee for control and supervision on experiments on Animals (CPCSEA) and the experimental protocols were duly approved by IAEC (Institutional Animal Ethics CommitteeSVCP/IAEC/I-003/2019-20).

\section{Drugs, chemicals, and instruments}

DOXO was procured from Sigma-Aldrich, U.S.A whereas assay kits like LDH \& creatine kinase-MB (CK-MB) were supplied by Crest Biosystems, Coral clinical systems, Goa, India. ROSS was received as a gift sample from Dr.N.N.Palei, Faculty of Pharmacy, Sree Vidyanikethan College of Pharmacy. All biochemical estimation was done using a semi-automatic analyzer (MispaVIVA, Agappe Diagnostics, Kerala, India) following the methods and stepwise procedures described by the manufacturers.

\section{Experimental design}

\section{Morphometric analysis}

Body weight of all experimental animals was recorded at regular intervals, whereas relative organ weight was calculated post-experimental period after sacrificing the animals. Heart weight was measured after washing it in ice-cold saline after removal from the body, squeezing out the blood, and blotted on the filter paper.

\section{Induction of cardiotoxicity}

A total of 24 Albino rats $(150 \pm 10 \mathrm{gm})$ were divided by following a random sampling technique into four groups of six animals each $(n=6)$. All the experimental animals were treated as per the study design and the duration of the treatment was continued up to 21 days.

Group I - Rats were given normal saline (1 mL/kg.s.c), Group II - Rats were given DOXO on $20^{\text {th }}$ day $(10 \mathrm{mg} / \mathrm{kg}$, i.p. $)$, 
Group III - Rats were given ROSS (10 mg/kg, p.o), Group IV - Rats were given ROSS (10 mg/kg, p.o) + DOXO (10 $\mathrm{mg} / \mathrm{kg}$, i.p.).

Cardiac toxicity was induced by a single intraperitoneal injection of DOXO at a dose of $10 \mathrm{mg} / \mathrm{kg}$ on the $20^{\text {th }}$ day of the experiment. ${ }^{14}$ At the end of the experimental period, After 48 $\mathrm{h}$ of DOXO injection, rats were anesthetized with mild ether anesthesia and blood samples were collected from retro-orbital plexus, and serum was separated by centrifugation at 10000 rpm for 10 min using a centrifuge (REMI, India).

\section{Estimation of cardiac and liver marker enzymes}

The separated serum sample was used to estimate the creatinine kinase-MB (CK-MB, measured by immune inhibition method by determining the rate of NADPH formation at $340 \mathrm{~nm}$ ) and liver markers enzymes such as aspartate aminotransferase (AST), alanine aminotransferase (ALT) and lactate dehydrogenase $(\mathrm{LDH})$, measured using ultraviolet kinetic method by observing the rate of nicotinamide adenine dinucleotide reduced form formation at $340 \mathrm{~nm}$ ) using an semi-automatic analyzer (Mispa-Viva-Agappe Diagnostics) with respective assay kits by following stepwise procedures given by the manufacturer. ${ }^{15-18}$

\section{Estimation of marker enzymes using post mitochondrial supernatant (PMS)}

Animals were sacrificed and the vital organ like heart was harvested for preparation of PMS. In brief, the harvested heart was per fused with ice-cold normal saline solution and homogenized using a phosphate buffer $(0.1 \mathrm{M}, \mathrm{pH} 7.4)$ and $\mathrm{KCl}$ $(1.17 \%, w / v)$ solution. Then the homogenate was centrifuged (800 rpm for $5 \mathrm{~min}$ at $4^{\circ} \mathrm{C}$ ) to separate the nuclear debris from the mixture. After that, the obtained supernatant was centrifuged at 10,500 rpm for 20 min at $4^{\circ} \mathrm{C}$ to obtain PMS. Collected PMS was used for analyzing for the presence of different enzymes related to $\mathrm{MI}$, such as CK-MB fraction and $\mathrm{LDH}$ using an semiautomatic analyzer (Mispa-Viva-Agappe Diagnostics). ${ }^{15-18}$

\section{Antioxidant activity}

Collected PMS solution from the heart tissue was used for measuring superoxide dismutase (SOD) ${ }^{19}$ and catalase (CAT) ${ }^{20}$ following standard procedures.

\section{Histopathological study}

The collected heart tissue was washed with ice-cold normal saline and fixed in formalin (10\% neutral) solution followed by embedding in paraffin. Then, it was sectioned ( $5 \mu \mathrm{m}$ thickness) and stained with hematoxylin and eosin for histopathological examination under a light microscope..$^{21}$

\section{Statistical analysis}

The statistical analysis was performed by ANOVA under OneWay classification followed by Dunnett's test. $p<0.05$ was considered statistically significant. Values are expressed as mean \pm standard error of the mean.

\section{RESULTS}

\section{Morphometric analysis}

Morphometric analysis of all experimental animals is tabulated in Table 1. Results depict that the body weight of experimental animals was recorded on a weekly interval of drug treatment. From the results, the administration of DOXO had shown significant changes in the body weight of animals, whereas acute administration of ROSS has shown a remarkable increase $(185.39 \pm 1.63, p<0.05)$ in body weight compared to control $(171.29 \pm 1.36)$ and DOXO $(164.45 \pm 2.49)$ treated group on day 21. However, heart weight and relative heart weight of experimental animals are summarized in Table 2. As per the results, heart weight followed by relative heart weight of rats received DOXO was statistically higher than control and ROSS received animals. But, treatment with ROSS significantly ( $p<0.05$ ) inhibited these weight variation changes influenced by DOXO administration and the obtained results were significantly ( $p<0.05)$ comparable with control groups.

\section{Cardiac marker enzymes}

The results presented in Figure 1 and Table 3 depicts the effect of ROSS on serum CK-MB levels against DOXO-induced cardiotoxicity in rats. Results indicate that DOXO received group 2 animals showed a significant raise of CK-MB levels $(p<0.05)$ compared to control animals. However, animals treated along with ROSS showed inhibitory action (** $p<0.01)$ on the raising level of CK-MB induced by DOXO in rats. Similarly, the same trend was noticed in LDH levels too. The results of the effect of ROSS on serum LDH levels are presented in Figure 2 and Table 3. After injection of DOXO, we observe that the rats in group II animals showed a marked rise in LDH levels ( $p<0.05$ ) compared with control groups. But the results from groups 3 and 4 show inhibitory action on the toxicity induced by DOXO in rats and the results were comparable with control animals.

Table 1. Effect of ROSS on morphometric analysis on DOXO induced cardiotoxicity

\begin{tabular}{|c|c|c|c|}
\hline \multirow{2}{*}{ Treatments (mg/kg, b.w) } & \multicolumn{3}{|c|}{ Body weight (gr) } \\
\hline & Day 7 & Day 14 & Day 21 \\
\hline CON (1 mL/kg, s.c.) & $143.39 \pm 1.67$ & $162.58 \pm 3.29$ & $171.29 \pm 1.36$ \\
\hline ROSS (10 mg/kg, p.o.) & $152.68 \pm 2.62$ & $165.37 \pm 1.79$ & $172.29 \pm 1.39$ \\
\hline ROSS $(10 \mathrm{mg} / \mathrm{kg}$, p.o. $)+\mathrm{DOXO}(10 \mathrm{mg} / \mathrm{kg}$, i.p. $)$ & $145.73 \pm 2.45$ & $173.42 \pm 2.56$ & $185.39 \pm 1.63^{*}$ \\
\hline
\end{tabular}

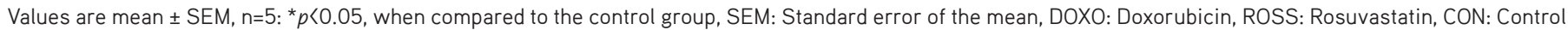




\section{Post mitochondrial supernatant}

The results of the effect of ROSS on heart tissue homogenate CK-MB levels are shown in Figure 3 and Table 3. After the injection of DOXO, we observe that rats in group II animals showed a remarkable rise in CK-MB levels $(p<0.05)$ in tissue

\begin{tabular}{|c|c|c|}
\hline \multirow[b]{2}{*}{ Treatments (mg/kg, b.w) } & \multicolumn{2}{|c|}{ Heart weight (mg) } \\
\hline & $\begin{array}{l}\text { Absolute heart } \\
\text { weight }\end{array}$ & $\begin{array}{l}\text { Relative heart } \\
\text { weight }\end{array}$ \\
\hline CON (1 mL/kg, s.c.) & $755 \pm 3.29$ & $0.44 \pm 0.06$ \\
\hline DOXO (10 mg/kg, i.p.) & $908 \pm 2.53$ & $0.55 \pm 0.08$ \\
\hline ROSS (10 mg/kg, p.o.) & $771 \pm 1.49$ & $0.44 \pm 0.04$ \\
\hline $\begin{array}{l}\text { ROSS (10 mg/kg, p.o.) + } \\
\text { DOXO (10 mg/kg, i.p.) }\end{array}$ & $774 \pm 4.56$ & $0.41 \pm 0.03$ \\
\hline
\end{tabular}

Values are mean \pm SEM, $n=5$. SEM: Standard error of the mean, DOXO: Doxorubicin, ROSS: Rosuvastatin, CON: Control

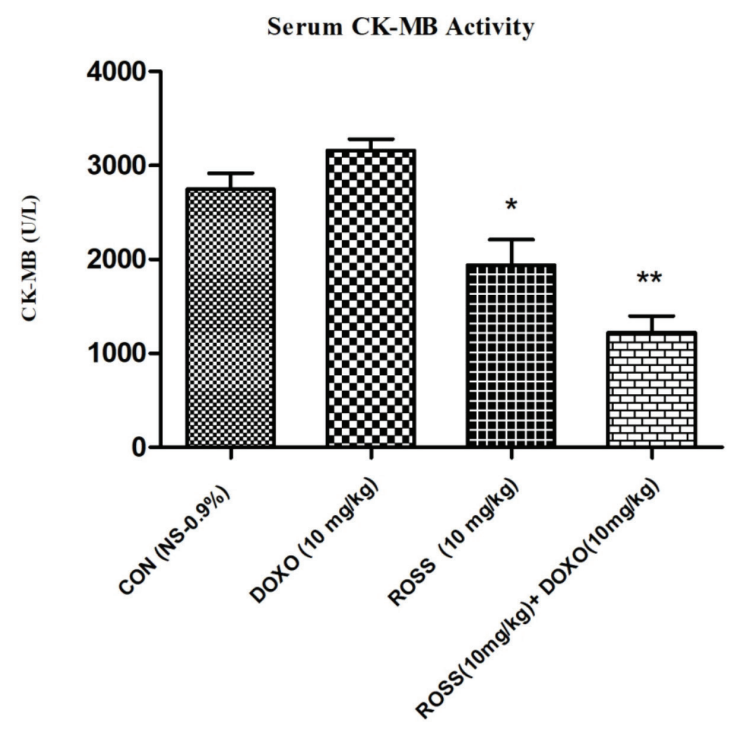

Figure 1. Effect of ROSS on serum CK-MB levels on DOXO-induced cardiotoxicity in rats

ROSS: Rosuvastatin, CK-MB: Creatine kinase-MB, DOXO: Doxorubicin, CON: Control homogenate compared with control groups. But the results from groups III and IV show the inhibitory action $(p<0.05)$ on the toxicity induced by DOXO in rats and the results were comparable with control animals.

\section{Liver marker enzymes}

The effects of ROSS on serum AST, ALT levels are summarized in Table 4. As per the obtained results, DOXO received animals showed marked rise of both AST $\left(240.34 \pm 5.53\right.$; $\left.{ }^{* *} p<0.001\right)$ and $\operatorname{ALT}\left(103.67 \pm 3.44 ;{ }^{* * *} p<0.001\right)$ whereas acute administration of ROSS significantly reversed these biochemical alterations to a significant extent incase of AST $\left(87.85 \pm 4.56\right.$; $\left.{ }^{* *} p<0.01\right)$ and ALT $\left(53.72 \pm 0.33^{* *},{ }^{* *} p<0.01\right)$ compared to DOXO and control animals.

\section{Antioxidant activity}

The effects of ROSS on antioxidant levels are presented in Table 5, Figure 4, 5. The results reveal that SOD and CAT levels were reduced in PMS solution of heart tissue of DOXO treated group II animals. Administration of DOXO showed marked reduction in SOD $(p<0.05)$ and CAT $(p<0.05)$ at dose of

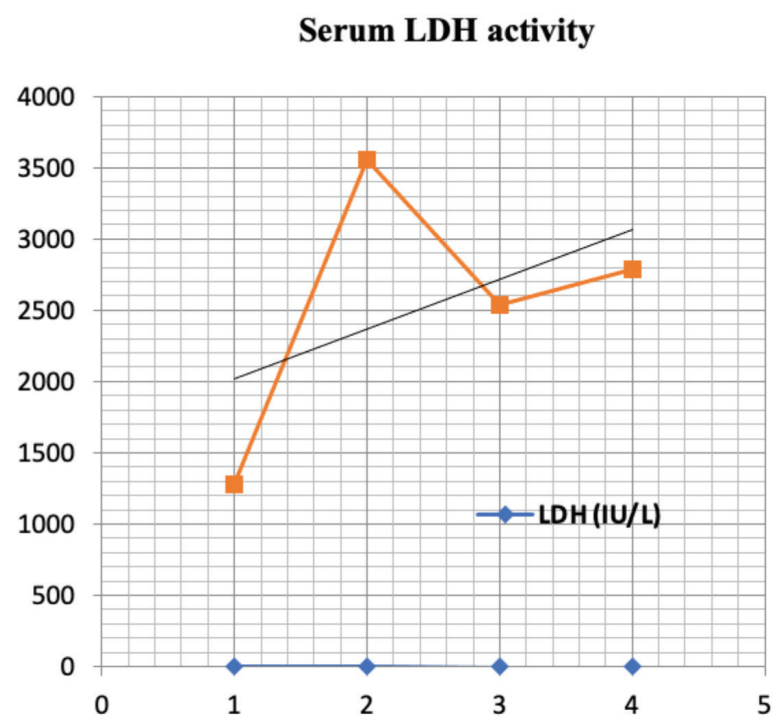

Figure 2. Effect of ROSS on serum LDH levels on DOXO-induced cardiotoxicity in rats

ROSS: Rosuvastatin, DOXO: Doxorubicin, LDH: Lactate dehydrogenase

Table 3. Effect of ROSS on creatine kinase-MB and lactate dehydrogenase levels on DOXO-induced cardio toxicity

\begin{tabular}{llll} 
& \multicolumn{3}{c}{ Marker enzymes } \\
\cline { 2 - 4 } Treatments (mg/kg, b.w) & CK-MB (U/L) (serum) & $\begin{array}{l}\text { CK-MB (U/L) (heart } \\
\text { tissue homogenate) }\end{array}$ & LDH (IU/L) (serum) \\
\hline CON $(1 \mathrm{~mL} / \mathrm{kg}$, s.c.) & $2912.05 \pm 4.59$ & $222.05 \pm 2.47$ & $1277 \pm 3.47$ \\
\hline DOXO $(10 \mathrm{mg} / \mathrm{kg}$, i.p. $)$ & $3157.32 \pm 3.62$ & $317.32 \pm 4.16$ & $3560 \pm 5.29$ \\
\hline ROSS $(10 \mathrm{mg} / \mathrm{kg}$, p.o. $)$ & $1973.37 \pm 7.48^{*}$ & $299.37 \pm 1.49$ & $2541 \pm 4.58^{*}$ \\
\hline ROSS $(10 \mathrm{mg} / \mathrm{kg}$, p.o. $)+$ DOXO $(10 \mathrm{mg} / \mathrm{kg}$, i.p. $)$ & $1091.62 \pm 2.39^{* *}$ & $235.62 \pm 2.36^{*}$ & $2789 \pm 4.39^{*}$ \\
\hline
\end{tabular}

Values are mean $\pm \mathrm{SEM}, \mathrm{n}=5,{ }^{*} p<0.05,{ }^{* *} p<0.01$, when compared to control and toxic control group, ROSS: Rosuvastatin, CK-MB: Creatine kinase-MB, LDH: Lactate dehydrogenase, DOXO: Doxorubicin, ROSS: Rosuvastatin, SEM: Standard error of the mean, CON: Control 


\begin{tabular}{|c|c|c|}
\hline \multirow{2}{*}{ Treatments (mg/kg, b.w) } & \multicolumn{2}{|c|}{ Liver marker enzymes } \\
\hline & AST $(I U / m L)$ & ALT (IU/mL) \\
\hline CON (1 mL/kg, s.c.) & $64.23 \pm 3.45$ & $43.48 \pm 2.57$ \\
\hline DOXO $(10 \mathrm{mg} / \mathrm{kg}$, i.p. $)$ & $240.34 \pm 5.53^{\star \star \star}$ & $103.67 \pm 3.44^{\star \star \star}$ \\
\hline ROSS (10 mg/kg, p.o.) & $131.67 \pm 3.49^{*}$ & $73.43 \pm 1.29 *$ \\
\hline $\begin{array}{l}\text { ROSS (10 mg/kg, p.o.)+ } \\
\text { DOXO (10 mg/kg, i.p.) }\end{array}$ & $87.85 \pm 4.56^{* *}$ & $53.72 \pm 0.33^{* *}$ \\
\hline
\end{tabular}

Values are mean $\pm \mathrm{SEM}, \mathrm{n}=5,{ }^{*} p<0.05,{ }^{* *} p<0.01$, when compared to control and toxic control group, ROSS: Rosuvastatin, CK-MB: Creatine kinase-MB, DOXO: Doxorubicin, ROSS: Rosuvastatin, AST: Aspartate aminotransferase, ALT: Alanine aminotransferase, SEM: Standard error of the mean, CON: Control

\section{Table 5. Effect of ROSS on Antioxidant levels on DOXO-}

induced cardiotoxicity

\begin{tabular}{|c|c|c|}
\hline \multirow[b]{2}{*}{ Treatments (mg/kg, b.w) } & \multicolumn{2}{|c|}{ Antioxidant enzymes } \\
\hline & $\begin{array}{l}\text { SOD }(\mu g / m g \\
\text { of protein) }\end{array}$ & $\begin{array}{l}\text { CAT }(U / m g \text { of } \\
\text { protein) }\end{array}$ \\
\hline CON (1 mL/kg, s.c.) & $45.86 \pm 1.49$ & $1.37 \pm 0.69$ \\
\hline DOXO (10 mg/kg, i.p.) & $32.6 \pm 2.32$ & $0.77 \pm 0.54$ \\
\hline ROSS (10 mg/kg, p.o.) & $58.7 \pm 1.56^{*}$ & $1.41 \pm 0.48^{*}$ \\
\hline $\begin{array}{l}\text { ROSS (10 mg/kg, p.o.) + DOXO } \\
(10 \mathrm{mg} / \mathrm{kg} \text {, i.p. })\end{array}$ & $60.9 \pm 1.58^{*}$ & $1.67 \pm 0.53^{*}$ \\
\hline
\end{tabular}

Values are mean $\pm \mathrm{SEM}, \mathrm{n}=5 .{ }^{*} p<0.05$, when compared to control and toxic control group, SEM: Standard error of the mean, DOXO: Doxorubicin, ROSS: Rosuvastatin, SOD: Superoxide dismutase, CAT: Catalase

\section{Heart tissue homogenate CK-MB Activity}

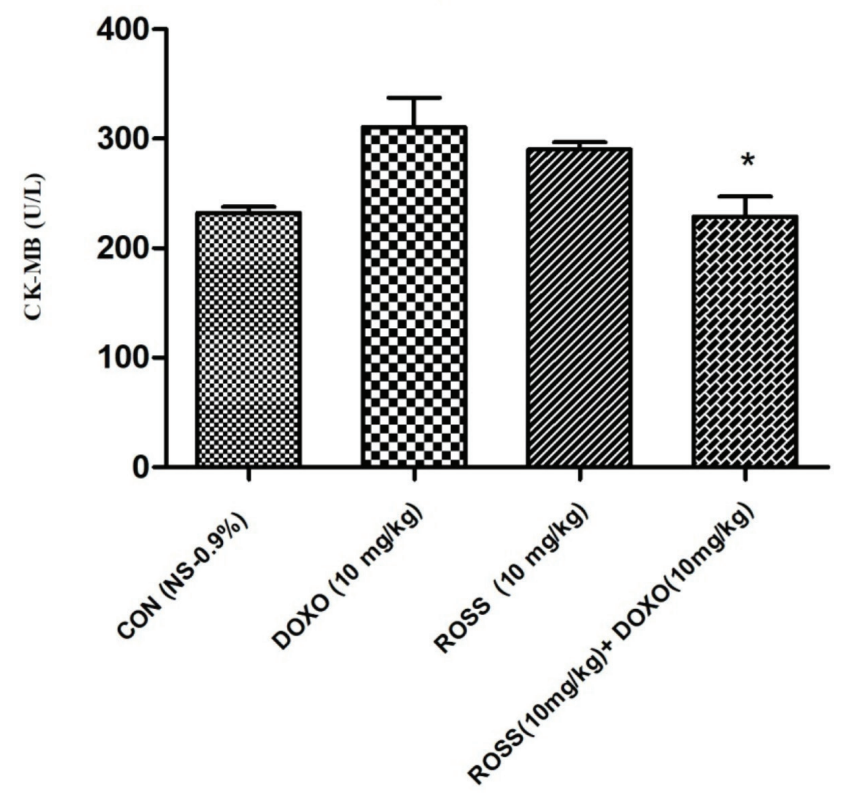

Figure 3. Effect of ROSS on CK-MB in heart tissues homogenate on DOXOinduced cardiotoxicity in rats

ROSS: Rosuvastatin, CK-MB: Creatine kinase-MB, DOXO: Doxorubicin, CON: Control
$10 \mathrm{mg} / \mathrm{kg}$. However, ROSS administration caused a reversal of depleted antioxidants to near normal levels, which indicated its protective and antioxidant capabilities.

\section{Histopathological study}

Histopathological observations of the cardiac tissues of all experimental groups are shown in Figure 6. From these results, cross-section of cardiac tissues of control animals showed normal myocardial architecture without inflammatory cell infiltration whereas necrotic cardiac tissue damage and like proliferated granulation tissues were seen in DOXO received animals. However, the administration of ROSS reversed these cellular changes to a remarkable significant extent with mild granulation tissue and restored normal cellular architecture, which reflects its protective potential against cardiotoxicity induced by DOXO.

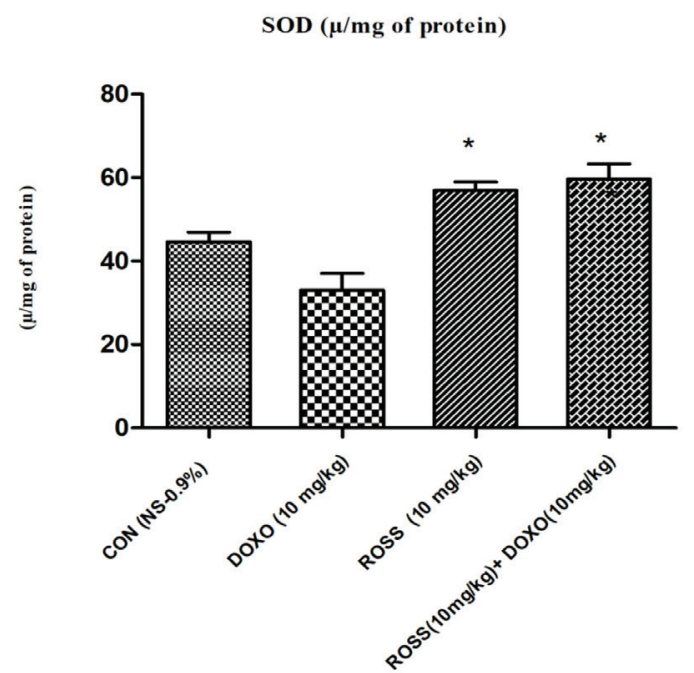

Figure 4. Effect of ROSS on SOD levels on DOXO-induced cardiotoxicity ROSS: Rosuvastatin, DOXO: Doxorubicin, SOD: Superoxide dismutase, CON Control

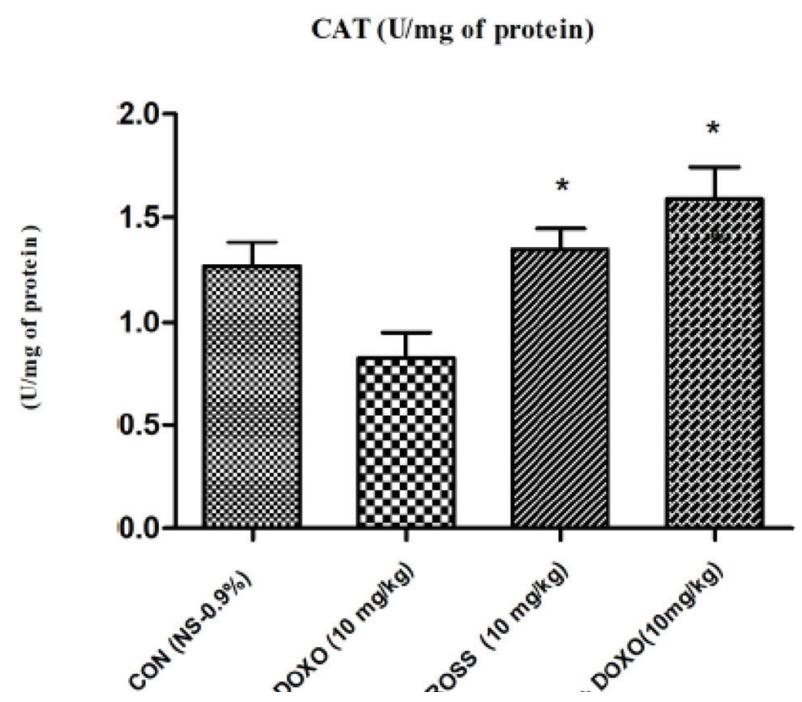

Figure 5. Effect of ROSS on CAT levels on DOXO-induced cardiotoxicity ROSS: Rosuvastatin, CAT: Catalase, DOXO: Doxorubicin, CON: Control 

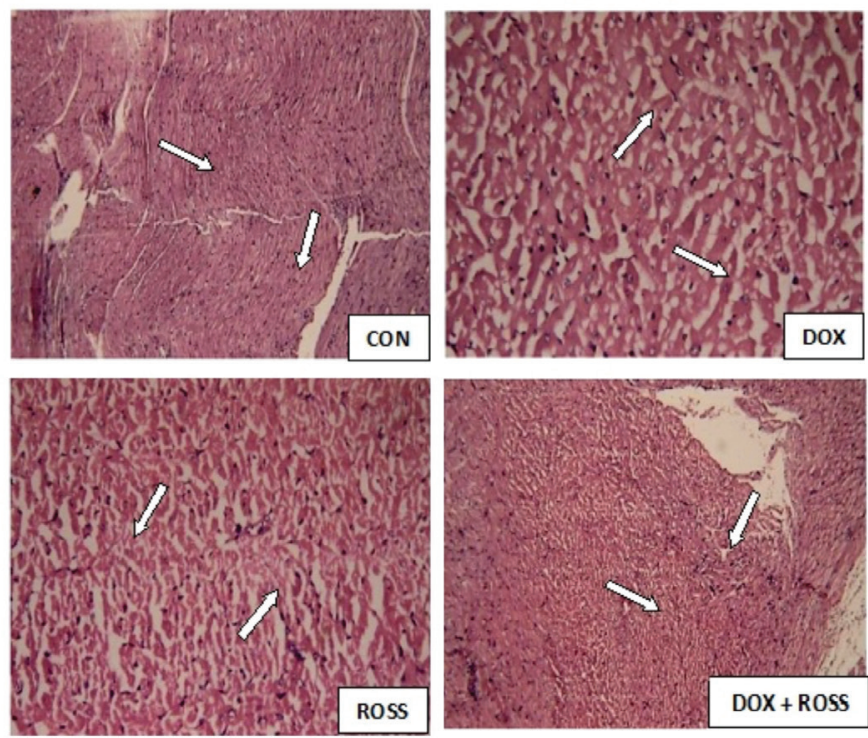

Figure 6. Histopathological observations of different experimental animals using hematoxylin and eosin staining (CON: Control animals showed normal myocardial cellular architecture, DOXO: Doxorubicin received groups showed noticeable necrotic cellular tissue damage, ROSS: Rosuvastatin treated groups; DOXO + ROSS: Doxorubicin plus rosuvastatin treated groups showed significant reversal of necrotic tissue damage caused by doxorubicin)

\section{DISCUSSION}

$\mathrm{Ml}$ is an acute necrotic disorder of the heart and one of the most commonly diagnosed forms of CVD in industrialized nations like India. It is a common and life-threatening manifestation of IHD leads to mortality. ${ }^{22} \mathrm{MI}$ is the technical name for a heart attack, occurring due to myocardial ischemia resulting from irreversible myocardial tissue necrosis because of complete occlusion of blood vessel (coronary artery) supplying blood to the myocardium. Therefore, the development of cardioprotective agents to improve myocardial function is of great clinical importance.

ROSS has shown significant organ protective properties with diverse pharmacological effects, including anti-inflammatory and antioxidative properties. ${ }^{23,24}$ Furthermore, according to studies, ROSS reduces oxidative stress by mediating many antioxidant effects, including decreased NADPH oxidase, suppression of endothelial nitric oxide synthase uncoupling, up regulation of antioxidant enzymatic defense mechanisms, and inhibition of hydrogen peroxide-induced DNA harm. ${ }^{25,26}$ But the experimental background found to be fertile or seem to have more gap to support the scientific background of diverse pharmacological profile of ROSS. Hence, the study elucidated the possible in vivo ameliorative influence of ROSS in DOXOinduced cardiotoxicity in rats.

DOXO is a well-known cardiotoxic agent capable of inducing cardiac injury in experimental animals and it is widely used model to induce cardiotoxicity. ${ }^{27} \mathrm{DOXO}$ destroys the myocardial cells, causing it to release cytosolic enzymes such as CK-MB, LDH, AST, and ALT into extra cellular fluid and in serum which indicates the myocardial tissue damage which was reflected in the study.
Results of this study indicate that, DOXO caused significant myocardial tissue damage, as indicated by a marked raise in the levels of cardiac injury markers, oxidative stress, heart weight, and histological changes in myocardial tissue, etc.

The same trend was noticed in heart tissue homogenate of DOXO treated animals compared with the control animals demonstrating the necrotic damage of the myocardial membrane by DOXO. Whereas ROSS-treated groups at doses of $10 \mathrm{mg} / \mathrm{kg}$ alone and in combination demonstrated a significant decline in CK-MB and LDH levels ( $p<0.05$ ), which ultimately reflects its protective activity against DOXO-induced cardiotoxicity in rats.

However, in the pathogenesis of various cardiovascular diseases, reports from earlier studies indicated the involvement of reactive oxygen species and the reduction of antioxidants. In this connection, it is well known that SOD is one of the important antioxidant enzymes to control many pathological progress in vast disease and disorders. In this study, increased levels of SOD to a significant extent $(p<0.05)$, which in turn reflects the protective role of ROSS. The same trend was observed in CAT too. CAT is also considered as one of the vital enzymes made of hemeprotein and used to scavenge the formed ROS, prevents the tissue damage against free radicals. ${ }^{28,29}$ Additionally, histopathological reports further corroborated the obtained results of the present investigations. As per the results, the administration of ROSS reversed cellular changes caused by DOXO to a significant extent and restored the normal cellular architecture, which reflects its protective potential against cardiotoxicity induced by DOXO.

\section{CONCLUSION}

Results from this study demonstrate that ROSS has shown promising potent cardioprotective effects on DOXO-induced cardiotoxicity in rats, as evidenced by the significant reduction of cardiac marker enzymes like CK-MB and LDH both in serum and in heart tissue homogenate along with significant reduction of liver marker enzymes like ALT, AST along with significant beneficial effects were seen in morphometric analysis. However, it is well recognized that various radical scavengers, such as CAT, SOD, and GPX, as well as GSH, serve as the first line of defense against oxidative damage, including cardiotoxicity. Reactive oxygen species can cause oxidative damage due to the lack of an appropriate endogenous antioxidant defense mechanism. The same were reflected in this study, which clearly indicated the diminishment of antioxidants such as SOD, CAT in DOXO treated animals. Thus, from the results, oxidative damage was clearly involved in DOXO-induced cardiotoxicity. However, the treatment of ROSS remarkably restored DOXOinduced cardiotoxicity by up-regulating the antioxidants. Thus, results from in vivo antioxidant study reflect that administration of ROSS significantly raised the level of SOD and CAT along with significant reversal of necrotic tissue damage caused by DOXO. Hence, it can be concluded that the cardioprotective potential of ROSS may be due to attenuation of cardiac, liver marker enzymes and oxidative stress by modulating oxidative damage by up-regulating the antioxidant defense mechanism. 


\section{ACKNOWLEDGMENTS}

The authors are grateful to the Principal and Management of Sree Vidyanikethan College of Pharmacy for providing the necessary facilities, and this research received no particular funding from any government, commercial, or non-profit organization.

Conflict of interest: No conflict of interest was declared by the authors. The authors are solely responsible for the content and writing of this paper.

\section{REFERENCES}

1. Ianaro A, lalenti A, Maffia P, Sautebin L, Rombolà L, Carnuccio R, luvone T, D'Acquisto F, Di Rosa M. Anti-inflammatory activity of macrolide antibiotics. J Pharmacol Exp Ther. 2000;292:156-163.

2. Singal PK, Pierce GN. Adriamycin stimulates low-affinity $\mathrm{Ca} 2+$ binding and lipid peroxidation but depresses myocardial function. Am J Physiol Heart Circ Physiol. 1986;250:H419-H425.

3. Thillaivanan S, Parthiban P, Kanakavalli K, Sathiyarajeshwaran P. A review on "Kapa Sura Kudineer"-a Siddha formulary prediction for swine flu. Int J Pharm Sci Drug Res. 2015;7:376-383.

4. Arya V, Gupta VK. Chemistry and pharmacology of plant cardio protective: a review. Int J Pharm Sci. 2011;2:1156-1167.

5. Nazish J, Ur-Rahman, Shoukat A. Cardioprotective, and antilipidemic potential of Cyprus rotundas in chemically induced cardiotoxicity. Int $J$ Agric Biol. 2012;14:989-992.

6. Geisberg CA, Sawyer DB. Mechanisms of anthracycline cardiotoxicity and strategies to decrease cardiac damage. Curr Hypertens Rep. 2010;12:404-410.

7. Octavia Y, Tocchetti CG, Gabrielson KL, Janssens S, Crijns HJ, Moens AL. Doxorubicin-induced cardiomyopathy: from molecular mechanisms to therapeutic strategies. J Mol Cell Cardiol. 2012;52:1213-1225.

8. Minotti G, Menna P, Salvatorelli E, Cairo G, Gianni L. Anthracyclines: molecular advances and pharmacologic developments in antitumor activity and cardiotoxicity. Pharmacol Rev. 2004;56:185-229.

9. Konorev EA, Kotamraju S, Zhao H, Kalivendi S, Joseph J, Kalyanaraman B. Paradoxical effects of metalloporphyrins on doxorubicin-induced apoptosis: scavenging of reactive oxygen species versus induction of heme oxygenase-1. Free Radic Biol Med. 2002;33:988.

10. Monetti M, Canavesi M, Camera M, Parente R, Paoletti R, Tremoli E, Corsini A, Bellosta S. Rosuvastatin displays anti-atherothrombotic and anti-inflammatory properties in apoE-deficient mice. Pharmacol Res. 2007;55:441-449.

11. Funderburg NT, Jiang Y, Debanne SM, Labbato D, Juchnowski S, Ferrari B, Clagett B, Robinson J, Lederman MM, McComsey GA. Rosuvastatin reduces vascular inflammation and T-cell and monocyte activation in HIV-infected subjects on antiretroviral therapy. J Acquir Immune Defic Syndr. 2015;68:396-404.

12. Miida T, Takahashi A, Ikeuchi T. Prevention of stroke and dementia by statin therapy: experimental and clinical evidence of their pleiotropic effects. Pharmacol Ther. 2007;113:378-393.
13. Duarte T, da Cruz IB, Barbisan F, Capelleto D, Moresco RN, Duarte MM The effects of rosuvastatin on lipid-lowering, inflammatory, antioxidant and fibrinolytics blood biomarkers are influenced by Val16Ala superoxide dismutase manganese-dependent gene polymorphism. Pharmacogenomics J. 2016;16:501-506.

14. Khatib NA, Mediswathi, Patel Jignesh. Evaluation of concomitant treatment of simvastatin and Zingiber Officinale in doxorubicin induced cardio toxicity in waster rats. IJRAP. 2011;2:660-664.

15. Reitman S, Frankel S. A colorimetric method for the determination of serum glutamic oxalacetic and glutamic pyruvic transaminases. Am J Clin Pathol. 1957;28:56-63.

16. Young DS. Effects of drugs on clinical laboratory tests. $3^{\text {rd }}$ ed. Washington, DC: AACC Press; 1990:356-357.

17. Tsung SH. "Creatine kinase activity and isoenzyme pattern in various normal tissues and neoplasms. Clin Chem. 1983;2040-2043.

18. Lorentz K, Klauke R, Schmidt E. Recommendation for the determination of the catalytic concentration of lactate dehydrogenase at 37 degrees C. Standardization Committee of the German Society for Clinical Chemistry, Enzyme Working Group of the German Society for Clinical Chemistry. Eur J Clin Chem Clin Biochem. 1993;31:897-899.

19. Kakkar P, Das B, Viswanathan PN. A modified spectrophotometric assay of superoxide dismutase. Indian J Biochem Biophys. 1984;21:130-132.

20. Aebi H. Catalase. In: Methods of enzymatic analysis. Bergmeyer HU (ed). Verlag, Chemic Academic Press Inc; 1974:673-685.

21. Talib VH. A handbook of medical laboratory technology. $2^{\text {nd }}$ ed. New Delhi: CBS Publisher and Distributors; 2007:155-167.

22. Patel V, Upaganlawar A, Zalawadia R, Balaraman R. Cardioprotective effect of melatonin against isoproterenol induced myocardial infarction in rats: a biochemical, electrocardiographic and histoarchitectural evaluation. Eur J Pharmacol. 2010;644:160-168.

23. Shen $P$, Zhang RN, Li F, et al. Diagnostic value of serum cystatin $C$ in early contrast nephropathy after coronary intervention. Laboratory Medicine and Clinic. 2018;15:2475-2478.

24. Chen Z, Cao Y, Qian J, Ma J, Zou Y, Ge J. Cardio protection of rosuvastatin against cardiac dysfunction after coronary microembolization via alleviating inflammatory induced micro infarctions. Circulation. 2015;132:A13434.

25. Grosser N, Erdmann K, Hemmerle A, Berndt G, Hinkelmann U, Smith G, Schröder $\mathrm{H}$. Rosuvastatin upregulates the antioxidant defense protein heme oxygenase-1. Biochem Biophys Res Commun. 2004;325:871-876.

26. Habibi J, Whaley-Connell A, Qazi MA, Hayden MR, Cooper SA, Tramontano A, Thyfault J, Stump C, Ferrario C, Muniyappa R, Sowers JR. Rosuvastatin, a 3-hydroxy-3-methylglutaryl coenzyme a reductase inhibitor, decreases cardiac oxidative stress and remodeling in Ren2 transgenic rats. Endocrinology. 2007;148:2181-2188.

27. Doroshow JH. Doxorubicin-induced cardiac toxicity. N Engl J Med. 1991;324:843-845

28. Chance B, Greenstein DS, Roughton RJW. The mechanism of catalase action1-steady-state analysis. Arch Biochem Biophys. 1952;37:301-321.

29. Yan $\mathrm{H}$, Harding JJ. Glycation-induced inactivation and loss of antigenicity of catalase and superoxide dismutase. Biochem J. 1997;328:599-605. 